\title{
TINJAUAN YURIDIS PERLINDUNGAN HUKUM HAK CUTI HAID DALAM UNDANG-UNDANG NO. 13 TAHUN 2003 TENTANG KETENAGAKERJAAN
}

\author{
Oleh:
}

Kadek Januarsa Adi Sudharma', Ida Ayu Ketut Artami² , Baby Rachella ${ }^{3}$

E-mail: januarsa.adi@undiknas.ac.id ${ }^{1}$, artami@undiknas.ac.id² , babyrachella1@gmail.com ${ }^{3}$

Dosen Fakultas Hukum dan Ilmu Sosial, Universitas Pendidikan Nasional

\begin{abstract}
Regulations regarding the right to menstrual leave for female workers in Indonesia are regulated in Law No. 13 of 2003 concerning Manpower. This law is the basis for the making of work agreements by every company in Indonesia, both a Fixed Time Work Agreement and an Indefinite Time Work Agreement. The work agreement is the basic principle of the relationship between workers and the company in relation to the type of work, wages, position and termination of employment. Legal protection for female workers in relation to the right to menstrual leave is implemented in article 81 paragraph (1) of Law No. 13 of 2003 concerning Manpower, usually in the form of requiring female workers to come to company clinics and have their conditions checked, if the conditions are declared unable to continue their work on that day, the female workers are given permission to rest at home. If at any time there is a dispute between workers and the company regarding menstrual leave, the dispute Resolution can be done in several ways. First, it can be resolved through negotiation by both parties or what is known as bipartite. If the bipartite settlement does not get satisfactory results for both parties, the case / dispute can be submitted to be resolved in an Industrial Relations Court.
\end{abstract}

Keywords: Dispute Resolution, Female Workers, Legal Protection, Menstrual leave rights

\begin{abstract}
Abstrak
Pengaturan mengenai hak cuti haid bagi tenaga kerja perempuan di Indonesia diatur dalam Undang-Undang No. 13 Tahun 2003 Tentang Ketenagakerjaan. Undang-undang ini menjadi dasar dalam pembuatan perjanjian kerja oleh setiap perusahaan di Indonesia baik Perjanjian Kerja Waktu Tertentu (PKWT) maupun Perjanjian Kerja Waktu Tidak Tertentu (PKWTT). Perjanjian kerja merupakan pokok dasar hubungan antara pekerja dan perusahaan kaitannya dengan jenis pekerjaan, upah, jabatan hingga pemutusan hubungan kerja. Perlindungan hukum bagi tenaga kerja perempuan kaitannya dengan hak cuti haid diimplementasikan pada pasal 81 ayat (1) Undang-Undang No. 13 Tahun 2003 Tentang Ketenagakerjaan, biasanya berupa mewajibkan pekerja perempuan untuk datang ke klinik perusahaan dan memeriksakan kondisinya, apabila kondisinya dinyatakan tidak mampu untuk meneruskan pekerjaannya pada hari tersebut, maka pekerja perempuan diberikan izin untuk beristirahat di rumah. Jika suatu saat terjadi perselisihan antara pekerja dan perusahaan kaitannya dengan cuti haid maka penyelesaian sengketa dapat dilakukan dengan beberapa cara. Pertama, dapat diselesaikan melalui cara perundingan oleh kedua belah pihak atau biasa disebut dengan bipartit. Bila dalam penyeselesaian bipartrit tidak mendapatkan hasil yang memuaskan bagi kedua
\end{abstract}


TINJAUAN YURIDIS PERLINDUNGAN HUKUM HAK CUTI HAID DALAM UNDANG-UNDANG NO. 13 TAHUN 2003 TENTANG KETENAGAKERJAAN (Januarsa Adi, dkk., 1-13)

belah pihak, perkara/perselisihan tersebut dapat diajukan untuk diselesaikan di pengadilan hubungan industrial.

Kata Kunci : Hak Cuti Haid, Perlindungan Hukum, , Penyelesaian Sengketa, Tenaga Kerja Perempuan

\section{PENDAHULUAN}

Manusia dilahirkan dan hidup tak terpisah antar satu dengan yang lain , melainkan berkelompok. Hidup berkelompok merupakan cara manusia mempertahankan hidup. Dikutip dari Kartohadiprodjo (2003:14), "Unsurunsur yang terdapat dalam diri manusia ada 4 (empat) yakni raga, rasa, rukun dan ratio. Manusia akan berusaha mempergunakan keempatnya dengan sebaik mungkin". Sehingga terdapat ketentraman, keseimbangan dan juga harmoni.

Kedudukan

hukum ketenagakerjaan di bidang hukum perdata terletak pada peranan penting yang ada pada hubungan antara pengusaha dengan pekerja. Dikutip dari Khoe (2013), "Secara yuridis dalam hukum perburuhan kedudukan pengusaha dan pekerja adalah sama dan sederajat, namun secara sosiologis pada suatu kondisi tertentu kedudukan antara pekerja dan pengusaha tidak sama dan seimbang dikarenakan seringkali pekerja berada pada posisi yang lemah","Berdasarkan Pasal 1 Angka 3 Undang-Undang Nomor 13 Tahun 2003 Tentang Ketenagakerjaan (selanjutnya disebut UU Ketenagakerjaan) pekerja atau buruh adalah setiap orang yang bekerja dengan menerima upah atau imbalan dalam bentuk lain. Pemberian upah ini menandakan adanya pemenuhan hak yang di dapatkan oleh pekerja dari perusahaan yang menunaikan kewajibannya."

Pekerja dalam melaksanakan perannya di masyarakat sebaiknya tidak dibedakan gender nya, baik lakilaki maupun perempuan dapat memberikan kontribusinya dalam pembangunan (Mambu,2010). Hal ini terkait pemberian kesempatan yang sama dalam memeroleh pekerjaan yang dijelaskan lebih lanjut dalam Pasal 5 UU Ketenagakerjaan. Pasal 5 menyebutkan "setiap tenaga kerja memiliki kesempatan yang sama tanpa diskriminasi untuk memeroleh pekerjaan."

Pemberian

kesempatan memeroleh pekerjaan telah diatur oleh UU Ketenagakerjaan, begitu pula mengenai pasal-pasal yang berkaitan tentang pengkhususan terhadap kaum perempuan. Beberapa isu pokok tenaga kerja perempuan yakni mengenai upah, diskriminasi tentang jaminan sosial, perlindungan kehamilan, bekerja pada malam hari, pemutusan hubungan kerja, keselamatan dan kesehatan kerja serta masih banyak lainnya.

"Perlindungan hukum bagi pekerja perempuan sangat dibutuhkan. Kaum perempuan secara kodrati memiliki sistem reproduksi sehingga berakibat pada fungsi reproduksi mereka seperti menstruasi/haid, melahirkan dan menyusui" (Nurendah, 2014:15). Terbentuknya Pasal 81 UU Ketenagakerjaan mengenai cuti haid yang menyatakan "pekerja/buruh perempuan yang dalam masa haid merasakan sakit dan memberitahukan kepada pengusaha tidak wajib bekerja pada hari pertama dan hari kedua pada waktu haid" ini merupakan 
keringanan yang dijamin oleh undangundang terhadap masa haid yang dialami perempuan.

Tujuan dan maksud dari dikeluarkannya regulasi UU Ketenagakerjaan ini adalah untuk memberikan rasa nyaman bagi pekerja perempuan namun dalam pelaksanannya peraturan yang diterapkan pemerintah tersebut masih belum maksimal. Pekerja perempuan masih belum mendapatkan hakhaknya sesuai dengan yang diharapkan. Contohnya saja mengenai cuti haid, dimana para pekerja perempuan tidak diperbolehkan cuti dan hanya diberikan waktu istirahat di klinik perusahaan.

Diskriminasi semacam ini juga akan berujung pada masalah pengupahan. Banyaknya kebutuhan khusus yang diperlukan kaum perempuan akan membuat perusahaan berpikir bahwa mempekerjakan perempuan adalah salah dan merepotkan (Husni, 2014:23). Hak-hak pekerja perempuan haruslah diberikah oleh perusahaan sesuai undang-undang yang telah mengaturnya, dengan tidak melupakan bahwa pekerja juga punya kewajiban terhadap perusahaan dalam keterkaitannya dengan hubungan kerja.

PT. Jakarana Tama (selanjutnya disebut PT. JT) merupakan sebuah industri pangan yang telah berdiri selama 35 tahun. Memulai bisnisnya sebagai distributor dan telah menjadi distributor terbesar di Indonesia pada 1992, kemudian dengan identitas yang baru, PT. JT pada akhirnya menjadi perusahaan yang memproduksi sendiri produk-produknya. Secara kontinyu telah memproduksi banyak brand pangan yang telah dipercaya dan tersebar baik dalam negeri maupun luar negeri
Sebagai perusahaan besar, PT. JT tak luput dari masalah hukum. Pada 19 November 2012 lalu, PT. JT melalui Pengadilan Negeri Bandung telah digugat oleh Dewi Yanti sebagai pekerja pada PT. JT sendiri dan sekaligus sebagai Ketua Serikat Buruh Fortuna. "Perkara ini adalah Perselisihan Hubungan Industrial yaitu berupa perselisihan pemutusan hubungan kerja. Oleh karenanya, sesuai ketentuan pasal 81 UndangUndang No. 2 Tahun 2004 tentang Penyelesaian Perselisihan Hubungan Industrial, gugatanpun dapat diajukan ke Pengadilan Hubungan Industrial ( yang selanjutnya disebut $\mathrm{PHI}$ ) pada Pengadilan Negeri yang daerah hukumnya meliputi tempat penggugat sebagai pekerja."

"PHI dibentuk berdasarkan Undang-Undang No. 2 Tahun 2004 tentang Penyelesaian Perselisihan Hubungan Industrial dengan ratio legis nya adalah mewujudkan kepastian hukum dan keadilan melalui asas peradilan cepat, tepat, adil dan murah.

Dewi Yanti menuntutkan haknya sebagai seorang pekerja. Sebagai seorang pekerja yang telah bekerja di PT. JT selama 18 tahun 4 bulan ia merasa terintimidasi oleh perusahaan yang memaksanya menandatangani Surat Peringatan (SP) 1 dan SP 2 dari pihak management tempatnya bekerja. Dewi Yanti saat itu meninggalkan pekerjaan dikarenakan sakit akibat haid dan pergi ke klinik perusahaan, namun pihak PT. JT tidak mampu untuk mentolerir keadaan tersebut sehingga terjadilah perselisihan antar kedua belah pihak yang mengakibatkan kerugian pada keduanya.

Dewi Yanti merasa rugi secara formil karena tidak menerima gaji pada saat setelah peristiwa berlangsung serta kerugian informil berupa 
gangguan psikis, sedangkan pihak PT. JT pun juga mendapatkan kerugian dikarenakan Dewi Yanti dianggap tidak mampu memenuhi tanggung jawabnya sebagai pekerja di perusahaan tersebut. Meski tidak disebutkan dalam peraturan perusahaan (PT. JT) pasal berapa yang mengatur mengenai cuti haid namun menurut keterangan saksi yakni Epon Poniawati dan Nining Sukarni yang berstatus sebagai pekerja juga pada PT. JT mengiyakan bahwa ada peraturan dari perusahaan, bagi pegawai yang mengalami haid dapat diberikan cuti selama 1 hari, tetapi untuk dapat diberikan cuti haid harus ada surat dari klinik yang ada di perusahaan (Mahkamah Agung, 2013)

\section{METODE}

Tinjauan ini dilakukan untuk identifikasi upaya yang dapat dilakukan agar ratio legis eksistensi $\mathrm{PHI}$ terwujud. Metode yang digunakan adalah penelitian hukum normative yang berdasarkan pada pengkajian hukum positif, yakni Undang-Undang No. 2 Tahun 2004 dengan pendekatan perundang-undangan untuk mengkaji asas-asas peradilan" (Tobing, 2018:8)

\section{PEMBAHASAN}

1. Pengaturan dan perlindungan hukum mengenai cuti haid bagi tenaga kerja perempuan di Indonesia dalam UU Ketenagakerjaan

Secara Lahiriyah, perempuan memang jauh berbeda dibandingkan laki-laki. Hal itu pula yang membedakannya dalam dunia kerja. Dikutip dari Mufidah (2010:7), "Pembedaan gender terjadi melalui proses panjang yag dilakukan manusia melalui gambaran diri, pemberian peran, cara memperlakukan serta penghargaan terhadap keduanya baik perempuan maupun laki-laki itu sendiri". Pembedaan peran dan tanggung jawab sampai saat ini masih sering menjadi topik permasalahan sehingga menyebabkan diskrimanasi terhadap gender.

Ketidakadilan gender adalah sistem dimana baik laki-laki atau perempuan menjadi korban sistem tersebut. Dikutip dari Fakih (2016:13), "Ketidakadilan gender dapat dilihat melalui berbagai macam manifestasi ketidakadilan yang ada seperti marginalisasi atau proses pemiskinan ekonomi, subordinasi atau anggapan tidak penting dalam keputusan politik, pelabelan negatif, kekerasan, beban kerja serta sosialisasi ideologi nilai peran gender".

Ketidakadilan pada kaum perempuan juga terjad pada peraturan yang mengatur mengenai hak cuti haid.

Undang-Undang

Ketenagakerjaan Pasal 81 ayat (1) menempatkan pekerja perempuan pada negosiasi tidak setara dengan majikan. Ketidaksetaraan tersebut terjadi dikarenakan posisi majikan yang menguasai alat produksi sangat dominan sehingga bisa memaksa pekerja perempuan untuk tunduk (Istakhori, 2017).

Mengatur pelaksanaan cuti haid, Undang-Undang Kerja Pasal 13 ayat (1) menyebutkan bahwa buruh perempuan tidak boleh diwajibkan bekerja pada hari pertama dan kedua waktu haid. Undang-Undang Kerja menegaskan "perlindungan afirmatif" dengan penegasan bahwa yang diberi kewenangan melarang pekerja perempuan melakukan pekerjaan pada hari pertama dan hari kedua waktu haid itu ialah perusahaan. "Implementasi Pasal 81 ayat (1) UU Ketenagakerjaan biasanya berupa mewajibkan pekerja perempuan untuk datang ke klinik perusahaan dan 
memeriksakan kondisinya, apabila kondisinya dinyatakan tidak mampu untuk meneruskan pekerjaannya pada hari tersebut, maka pekerja perempuan diberikan izin untuk beristirahat di rumah. Hal ini tidaklah mendukung pekerja perempuan secara penuh, dikarenakan rasa sakit akibat haid bisa saja timbul sebelum pekerja perempuan sampai di perusahaan dan melakukan pekerjaannya, misalnya sesaat sebelum berangkat bekerja atau pada malam hari dan jauh sebelum pekerja perempuan memulai aktivitasnya di perusahaan."

Sesuai Pasal 93 UU Ketenagakerjaan yang menyatakan bahwa upah tidak dibayar apabila pekerja tidak melakukan pekerjaannya kecuali diantaranya pekerja perempuan yang sakit pada hari pertama dan kedua masa haidnya sehingga tidak dapat melakukan pekerjaan. "Negatifnya, cuti haid merupakan suatu tindakan yang dinilai merusak konsistensi kinerja dikarenakan tidak semua kaum perempuan mengalami rasa sakit karena haid. Hal ini dapat menjadi celah bagi pekerja perempuan lain untuk mangkir dan bolos kerja."

Perlindungan hukum bagi tenaga kerja utamanya terhadap pekerja perempuan agar hak-hak dasar pekerja mendapat perlakukan yang sama tanpa diskriminasi atas dasar apapun dapat terjamin dengan tetap melihat perkembangan kemajuan dunia usaha (Wijayanti, 2010). Dikutip dari Soeroso (2006:49), "Perlindungan hukum timbul karena adanya suatu hubungan hukum. Hubungan hukum merupakan interaksi antara subjek hokum yang mempunyai relevansi hukum atau akibat hukum yaitu timbulnya hak dan kewajiban." Teori perlindungan hokum mengintegrasikan dan mengkoordinasikan berbagai kepentingan dalam masyarakat dengan cara mengatur perlindungan dan pembatasan terhadap berbagai kepentingan tersebut sehingga tidak terjadi abuse of power.

Perlindungan berarti mengayomi sesuatu dari hal-hal yang berbahaya. Dapat juga berarti pengayoman yang diberikan seseorang terhadap orang lain yang lebih lemah dalam hal ini ialah pekerja perempuan itu sendiri. Konteks perlindungan hukum disini juga dapat diartikan segala upaya pemerintah sebagai pembuat peraturan dalam menjamin hak-hak pekerja perempuan sebagai bagian dari warga negara Indonesia agar tidak dilanggar oleh pihak-pihak tertentu (Lestari Clinto, 2016).

Pelaksanan perlindungan hukum hak cuti haid juga mengacu pada "Peraturan Pemerintah Republik Indonesia No. 78 Tahun 2015 Tentang Pengupahan yaitu ketentuan Pasal 24 Ayat (3) huruf b" yang mengatur: "Pekerja/buruh perempuan yang sakit pada hari pertama dan kedua masa haidnya sehingga tidak dapat melakukan pekerjaan". "Di dalam ketentuan Pasal 1 Angka (1) UndangUndang Nomor 39 Tahun 1999 tentang Hak Asasi Manusia, memberikan rumusan tentang pengertian Hak Asasi Manusia" sebagai berikut: "Seperangkat hak yang melekat pada hakikatnya dan keberadaan manusia sebagai makhluk Tuhan Yang Maha Esa dan merupakan anugerah-Nya yang wajib dihormati, dijunjung tinggi dan dilindungi oleh Negara, hukum, pemerintah, dan setiap orang demi kehormatan serta perlindungan harkat dan martabat manusia" (Asyhadie, 2007:58)

Preventif dalam perlindungan hukum cuti haid dapat dilihat dari 
TINJAUAN YURIDIS PERLINDUNGAN HUKUM HAK CUTI HAID DALAM UNDANG-UNDANG NO. 13 TAHUN 2003 TENTANG KETENAGAKERJAAN (Januarsa Adi, dkk., 1-13)

adanya peraturan perundangundangan yang telah dibuat dan berguna sebagai tindakan pencegahaan pelanggaran norma terhadap perempuan yang sedang mengalami haid pada masa kerja. Sedangkan represifnya berupa tindak lanjut yang dapat ditempuh baik oleh pekerja perempuan atau perusahaan apabila terjadi konflik yang berkaitan dengan cuti haid. Penyelesaian sengketa ini dapat diselesaikan melalui kekeluargaan maupun dibawa ke jalur hukum guna menemukan solusi terbaik dari permasalahan yang ada. Baik aturan hukum yang bersifat tertulis maupun tidak tertulis, preventif maupun represif, itu semua bertujuan untuk memberikan rasa aman sebagai warga negara, tidak hanya untuk pekerja perempuan melainkan juga untuk perusahaan (Widianti, 2005:12). Aturan hukum tersebut untuk akan memberikan keadilan dan kepastian hukum bagi kedua belah pihak, yakni antara perusahaan dengan pekerjanya. "Pengaturan dan perlindungan hukum mengenai cuti haid bagi tenaga kerja perempuan di Indonesia dalam UU Ketenagakerjaan tidaklah mendukung perempuan secara penuh dikarenakan implementasi dari hak cuti haid yang tercantum dalam Pasal 81 UU Ketenagakerjaan diserahkan kembali kepada pihak perusahaan yang nantinya dituangkan dalam peraturan perusahaan atau perjanjian kerja bersama, menjadikan pihak perusahaan lebih dominan terhadap pekerja perempuan dalam pembuatan peraturan."

\section{Penyelesaian sengketa antara pekerja dengan perusahaan terkait tidak terpenuhinya cuti haid}

Beberapa perusahan seperti contohnya PT. JT menyediakan klinik perusahaan yang salah satu fungsinya ialah untuk pengecekan kondisi pekerja perempuan saat sedang masa haid. Konsepnya, pekerja perempuan yang haid dan merasakan sakit pada hari pertama dan atau hari kedua masa haidnya harus memeriksakan terlebih dahulu ke klinik perusahaan untuk mendapatkan surat keterangan dokter (Djakaria,2018).

Seperti halnya Dewi Yanti sebagai salah satu pekerja pada PT. JT yang menerapkan hak cuti haidnya pada perusahaan. Dewi Yanti melakukan pekerjaannya dengan penuh tanggung jawab dan dibuktikan oleh masa pengabdian kepada PT. JT selama 18 tahun 4 bulan (delapan belas tahun empat bulan). Pada 27 Oktober 2011 tepatnya pukul 11.00 Waktu Indonesia Barat (WIB) Dewi Yanti pergi ke klinik perusahaan dalam kondisi harus segera memeriksakan dirinya dengan cara menitipkan izin pada salah satu rekan kerjanya. Mengingat pekerja adalah pihak yang lemah dari pengusaha yang kedudukannya lebih kuat maka pekerja perlu mendapatkan perlindungan atas hak-haknya (Dwiyanda, 2020). Sudah menjadi hak pekerja apabila merasakan sakit pada dirinya maka harus diperiksakan kondisi kesehatannya seperti demikian pula yang dilakukan oleh Dewi Yanti.

Dikutip dari Hakim (2003:61), "Perlindungan tenaga kerja dibagi menjadi 3 (tiga) macam, yaitu perlindungan ekonomis dalam bentuk penghasilan yang cukup, perlindungan social dalam bentuk jaminan kesehatan kerja, perlindungan teknis dalam bentuk keamanan dan keselamatan kerja”.

Berdasarkan Posisi Kasus yang tertuang dalam Putusan $\mathrm{PHI}$ 
Mahkamah Agung Nomor 409 K/Pdt.Sus-PH/2013, dijelaskan Dewi Yanti yang juga berperan sebagai Ketua Serikat Buruh Fortuna menerima Surat Peringatan (selanjutnya SP) 1 dari pihak supervisor dengan alasan meninggalkan pekerjaan yang kemudian SP 1 tersebut ditolak oleh Dewi Yanti. Setelah penolakan tersebut, Dewi Yanti yang tetap berada di ruangan supervisor merasa tersinggung oleh atasannya yaitu Pak Buchin yang terus menerus mengungkit permasalahan rumah tangga dan anak Dewi Yanti. Hal tersebut membuat Dewi Yanti stress dan masih dalam keadaan masa haid. Masih pada hari yang sama, tepatnya pukul 16.00 WIB, Dewi Yanti diminta dan ditekan untuk menandatangani SP 2.

Perlindungan pekerja dapat dilakukan dengan cara memberikan tuntunan maupun dengan jalan meningkatkan pengakuan hak-hak asasi manusia, perlindungan fisik dan teknik serta social ekonomi melalui undang-undang dalam tempat kerja. Dikutip dari Asikin (2010:75), "Perlindungan pekerja mencakup norma keselamatan pekerjaan, norma kesehatan kerja, norma kerja dan kepada pekerja yang mendapat pekerjaan kecelakaan atau sakit karena pekerjaannya". Praktiknya, "objek perlindungan tenaga kerja yang diatur dalam UU Ketenagakerjaan menyebutkan bahwa para pekerja perempuan memiliki perlindungan yang khusus karena kondisi biologis yang berbeda dengan pekerja laki-laki. Perlindungan hukum kepada pekerja perempuan tersebut merupakan suatu pemenuhan hak dasar yang melekat dan dilindungi oleh konstitusi. Salah satu perlindungan hukum yang dikhususkan untuk pekerja perempuan adalah perlindungan yang bersifat protektif. UU Ketenagakerjaan memberikan hak kepada pekerja perempuan untuk libur bekerja di hari pertama dan hari kedua saat merasakan sakit masa haid sebagaimana ketentuan Pasal 81 ayat (1)."

Indonesia sendiri, "terdapat 2 bentuk perjanjian kerja yang diatur di dalam peraturan perundangundangan, yaitu Perjanjian Kerja Waktu Tertentu (yang selanjutnya disebut dengan PKWT) untuk pekerja kontrak, dan Perjanjian Kerja Waktu Tidak Tentu (yang selanjutnya disebut PKWTT) untuk pekerja tetap (Sudharma,2020). Ketentuan yang mengatur mengenai PKWT ada di dalam Pasal 56 ayat (2) UU Ketenagakerjaan yang menyebutkan bahwa perjanjian kerja untuk waktu tertentu (PKWT) didasarkan atas jangka waktu atau selesainya satu pekerjaan tertentu." (Rusli, 2011)

Menurut ketentuan, "seharusnya pekerja perempuan yang terikat PKWT atau harian lepas maupun dalam PKWTT diberikan masa cuti saat hari pertama dan hari kedua masa haid yang telah diatur dalam UU Ketenagakerjaan akan tetapi praktiknya, masih banyak perusahaan yang tidak memberikan cuti haid kepada para pekerja perempuan sehingga seringkali terjadi dalam praktik banyak pekerja perempuan harian lepas yang diberikan pemutusan hubungan kerja oleh perusahaan (Flambonita, 2017)."

Dewi Yanti yang statusnya sebagai PKWTT pada PT. JT mendapatkan telepon dari pihak Management bahwa dirinya tidak boleh bekerja sejak bulan Desember 2011 dan sudah tidak menerima gajinya. Tanggal 13 Januari 2012 Dewi Yanti menghubungi Pak Prapto (HRD) 
via telepon dan menyampaikan bahwa gaji bulan Desember tidak ditransfer perusahaan ke rekeningnya. Oleh Pak Prapto dikatakan bahwa itu atas permintaan Pak Royke dengan alasan Dewi Yanti sudah tidak bekerja. Dewi Yanti menyatakan bahwa dia berusaha untuk masuk kerja tetapi dia tidak diperbolehkan masuk."Pemutusan hubungan kerja terhadap pekerja perempuan akan menjadikan pekerja perempuan tersebut kehilangan mata pencaharian, yang berarti pula awal mula masa pengangguran dengan segala akibatnya. Hal ini juga berarti tidak tercukupinya kebutuhan hidup dirinya dan keluarganya untuk bertahan hidup. Pemutusan Hubungan Kerja (selanjutnya PHK) yang dilakukan oleh PT. JT disebabkan pekerja Dewi Yanti berhalangan menjalankan pekerjaan atau melanggar perjanjian kerja dikarenakan masa haid yang dalam hal ini dianggap merugikan pihak perusahaan sehingga pihak perusahaan tidak memberikan cuti pada pekerja, padahal pemberian cuti itu sudah menjadi kewajibannya selain memberi upah."Landasan hukum perikatan di dalam hubungan Industrial antara perusahaan dengan pekerja adalah perjanjian kerja yang mana tercantum di dalam Pasal 50 UU Ketenagakerjaan bahwa Hubungan kerja terjadi karena adanya perjanjian kerja antara pengusaha dengan pekerja/ buruh.".

Menurut ketentuan, "subjek atau para pihak dalam hubungan kerja adalah pemberi kerja atau pengusaha dan pekerja. Perjanjian kerja sendiri merupakan perjanjian yang menjelaskan tentang kerja, yang berarti dengan adanya perjanjian kerja maka timbul adanya hak dan kewajiban suatu pihak untuk melakukan suatu pekerjaan (Ramly,
2008). Hubungan antara para pekerja dengan perusahaan ini adalah saling membutuhkan satu sama lain, yang mana di satu sisi pekerja membutuhkan perusahaan untuk mereka mencari nafkah dan disisi lain perusahaan juga membutuhkan pekerja sebagai sumber daya untuk menggerakkan perusahaan (Sugita,2014)."“PHK Terhadap Pekerja Karena Cuti Haid tidak dapat dilakukan dengan sewenang-wenang oleh perusahaan, dalam Pasal 153 UU Ketenagakerjaan telah menentukan alasan-alasan yang tidak boleh dijadikan dasar permohonan penetapan $\mathrm{PHK}$, antara lain : Pekerja yang berhalangan bekerja karena sakit menurut keterangan dokter selama waktu tidak melampaui 12 (dua belas) bulan secara terus menerus; Pekerja tidak dapat menjalankan pekerjaannya karena memenuhi kewajiban terhadap negara sesuai dengan ketentuan peraturan perundangundangan; Pekerja yang sedang menjalankan ibadah agamanya; Pekerja menikah; Pekerja perempuan yang sedang hamil, melahirkan, gugur kandungan, atau menyusui anaknya; Pekerja yang mempunyai pertalian darah dan/atau ikatan perkawinan dengan pekerja lainnya di suatu perusahaan, kecuali telah disepakati di suatu perjanjian kerja, peraturan perusahaan, atau perjanjian kerja bersama; Pekerja mendirikan, menjadi anggota/pengurus serikat pekerja, melakukan kegiatan serikat pekerja di luar atau di dalam jam kerja atas kesepakatan pengusaha, berdasarkan ketentuan dalam perjanjian kerja, peraturan perusahaan, atau perjanjian kerja bersama; Pekerja yang mengadukan pengusaha atau pemberi kerja kepada pihak yang berwajib atas perbuatan pengusaha atau pemberi kerja yang melakukan tindak pidana kejahatan; 
Pekerja yang memiliki perbedaan paham, agama, aliran politik, suku, warna kulit, golongan, jenis kelamin, kondisi fisik, atau status perkawinan; Pekerja dalam keadaan cacat tetap, sakit akibat kecelakaan kerja, atau sakit karena hubungan kerja yang menurut surat dokter jangka waktu penyembuhannya belum dapat dipastikan.."'Dari penjelasan dan ketentuan-ketentuan diatas berlaku kepada seluruh tenaga kerja yang memiliki hubungan kerja PKWTT maupun yang memiliki hubungan kerja PKWT."Apabila terjadi PHK dengan alasan tersebut di atas, maka menurut Pasal 153 ayat (2) UU Ketenagakerjaan PHK tersebut batal demi hukum dan perusahaan wajib mempekerjakan kembali pekerja yang bersangkutan. Batal demi hukum yang dimaksud ialah PHK tersebut dianggap tidak pernah ada atau dapat tidak sah karena tidak terpenuhinya syarat objektif.

Dewi Yanti sebagai pekerja diwajibkan untuk tetap melaksanakan pekerjannya dan PT. JT berkewajiban untuk tetap membayarkan upah Dewi Yanti selama Lembaga Penyelesaian Hubungan Industrial belum mempunyai kekuatan hukum tetap (Vide Putusan Mahkamah Konstitusi Nomor 37 Tahun 2011).

PHK terhadap PKWTT maupun PKWT dapat tetap dilakukan, dengan catatan perusahaan wajib membayar uang pesangon dan atau uang penghargaan masa kerja dan uang penggantian hak yang seharusnya diterima sesuai yang diatur dalam Pasal 156 UU Ketenagakerjaan. Apabila PHK dilakukan terhadap pekerja PKWT sebelum berakhirnya jangka waktu yang ditetapkan dalam perjanjian kerja waktu tertentu tersebut, perusahaan wajib membayar ganti rugi kepada pekerja sebesar upah pekerja sampai batas waktu berakhirnya jangka waktu perjanjian kerja, hal ini telah diatur dalam ketentuan yang diatur dalam Pasal 62 UU Ketenagakerjaan."Pasal 1 angka 22 UU Ketenagakerjaan jo. Pasal 1 angka 1 Undang-Undang Nomor 2 tahun 2004 tentang Penyelesaian Perselisihan Hubungan Industrial dirumuskan pengertian perselisihan hubungan industrial" yaitu "Perbedaan pendapat yang mengakibatkan pertentangan antara pengusaha atau gabungan pengusaha dengan pekerja atau serikat pekerja karena adanya perselisihan mengenai hak, perselisihan kepentingan dan perselisihan PHK serta perselisihan antara serikat pekerja hanya dalam satu perusahaan" Dikutip dari Husni (2004:3), "Unsur-unsur perselisihan yaitu adanya pihak dalam perselisihan, terdapat tujuan yang tidak sama serta keinginan salah satu pihak tidak sama". Perselisihan antara pekerja dengan perusahaan yang tidak dapat diselesaikan dengan cara musyawarah akan diselesaikan di $\mathrm{PHI}, \mathrm{PHI}$ bertugas dan berwenang memeriksa dan memutus mengenai hubungan industrial sebagaimana yang jelaskan di ketentuan Pasal 56 UU PPHI. "mmmmm

Penyelesaian $\begin{array}{r}\text { perselisihan } \\ \text { industrial }\end{array}$
dabungan
menggunakan 2 (dua) jalur untuk
menyelesaikan yakni melimpahkan
perselisihan tersebut kepada seorang
ahli sebagai penengah atau biasa
disebut voluntary arbitration, atau
menyerahkan masalah perselisihan
kepada PHI yang mana masalah akan
diselesaikan berlandaskan peraturan
perundang-undangan yang berlaku
(Charda, 2017). Setiap perselisihan
hubungan industrial harus dilakukan
terlebih dahulu dengan cara
perundingan oleh kedua belah pihak


atau biasa disebut dengan bipartit. Para pihak dalam bipartit ini terdiri dari perwakilan pengusaha dan perwakilan pekerja dan atau serikat pekerja." Terjadi pula pada kasus Dewi Yanti dengan pihak PT. JT, dimana Dewi Yanti dipanggil oleh pihak Management untuk pertemuan bipartit, membahas mengenai permintaan Dewi Yanti untuk menarik kembali SP 2. Pada Pasal 106 UU Ketenagakerjaan telah mengatur bahwa "perusahaan untuk membentuk lembaga bipartit apabila mempekerjakan 50 (lima puluh) orang pekerja/buruh atau lebih", kemudian disebutkan juga dalam ayat (2) bahwa "lembaga kerja sama bipartit sebagaimana dimaksud dalam ayat (1) berfungsi sebagai forum komunikasi, dan konsultasi mengenai hal ketenagakerjaan di perusahaan."

Apabila telah terjadi perselisihan hubungan industrial, maka telah diatur langkah-langkah selanjutnya yang harus diambil. Dalam Pasal 3 UU PPHI, Ayat (1) : "Perselisihan hubungan industrial wajib diupayakan penyelesaiaannya terlebih dahulu melalui perundingan bipartit secara musyawarah untuk mencapai mufakat". Ayat (2): "Penyelesaian perselisihan melalui bipartit sebagaimana dimaksud dalam ayat (1), harus diselesaikan paling lama 30 (tiga puluh) hari kerja sejak tanggal dimulainya perundingan". Ayat (3): "Apabila dalam jangka waktu 30 (tiga puluh) hari sebagaimana dimaksud dalam ayat (2) salah satu pihak menolak untuk berunding atau telah dilakukan perundingan tetapi tidak mencapai kesepakatan, maka perundingan bipartit dianggap gagal"

Proses mediasi pun sebenarnya telah dicoba oleh Dewi Yanti dan PT. JT di Dinas Tenaga dan Transmigrasi Kabupaten Bogor namun berakhir gagal juga. Atas dasar tersebut, Dewi Yanti mengajukan permohonan PHK dan oleh karena itu, harus ada penetapan dari Lembaga Perselisihan Hubungan Industrial. Hal ini sesuai amanat pasal 169 ayat (1) UU Ketenagakerjaan pekerja dapat mengajukan permohonan pemutusan hubungan kerja kepada lembaga penyelesaian perselisihan hubungan industrial.

Pasal 95 ayat (2) dan (3) UU Ketenagakerjaan menetapkan "Pengusaha yang karena sengaja atau kelalaiannya mengakibatkan keterlambatan pembayaran upah, dikenakan denda sesuai presentase tertetntu dari upah pekerja/buruh. Pemerintah mengatur pengenaan denda kepada pengusaha dan/ atau pekerja/buruh, dalam pembayaran upah". Pasal ini diperkuat dengan pasal 19 ayat (1) Peraturan Pemerintah Nomor 8 Tahun 1981 Tentang Perlindungan Upah yang menyatakan apabila upah terlambat dibayarkan. Terhitung dari ke 4 (empat) samapai ke 8 (delapan) dimana seharusnya upah dibayar, upah tersebut ditambah 5\% (lima persen) untuk tiap hari keterlambatan.

Penyelesaian sengketa antara pekerja dengan perusahaan terkait tidak terpenuhinya cuti haid seperti contoh yang terjadi pada kasus Dewi Yanti dengan PT. JT adalah satu diantara beberapa kasus di Indonesia yang berakhir di pengadilan. Walaupun pada awal mula kasus sempat dicoba diselesaikan dengan bipartrit dan mediasi namun penyelesaian kasus di luar pengadilan dianggap tidak bisa memberikan titik temu untuk kedua belah pihak. Berdasarkan contoh kasus tersebut diharapkan kedepannya antara pihak pekerja maupun pengusaha secara bersama-sama memahami peraturan 
perusahaan dan kontrak kerja yang telah disepakati, sehingga kasus terjadi dapat segera diselesaikan dengan musyawarah mufakat atau dalam tahap bipartit yakni antara pekerja dengan pengusaha.

\section{PENUTUP}

Bahwa pengaturan tentang cuti haid di Indonesia diatur dalam UU Ketenagakerjaan namun dalam UU Ketenagakerjaan tersebut memberikan beban pada pekerja perempuan untuk berusaha sendiri, yakni apabila pekerja perempuan merasakan sakit pada hari pertama dan kedua haid dan memberitahukannya, tidak diwajibkan bekerja. Sedangkan, Pasal 81 ayat (2) menempatkan buruh perempuan berhadapan langsung dengan majikan melalui negosiasi tidak setara. Negosiasi tidak setara yang dimaksud ialah adanya perjanjian kerja, peraturan perusahaan atau perjanjian kerja bersama yang ditanda tangani oleh pekerja yang akan bekerja di suatu perusahaan."Setiap perselisihan hubungan industrial harus dilakukan terlebih dahulu dengan cara perundingan oleh kedua belah pihak atau biasa disebut dengan bipartit. Para pihak dalam bipartit ini terdiri dari perwakilan pengusaha dan perwakilan pekerja dan atau serikat pekerja. Apabila dalam jangka waktu 30 (tiga puluh) hari salah satu pihak menolak untuk berunding atau telah dilakukan perundingan tetapi tidak mencapai kesepakatan, maka perundingan bipartit dianggap gagal. Perselisihan antara pekerja dengan perusahaan yang tidak dapat diselesaikan dengan cara musyawarah akan diselesaikan di $\mathrm{PHI}, \mathrm{PHI}$ bertugas dan berwenang memeriksa dan memutus mengenai hubungan industrial."

Pemerintah khususnya Dewan Perwakilan Rakyat harus memperjelas sanksi terhadap pelanggaran hak cuti haid yang tercantum dalam UU Ketenagakerjaan karena sanksi yang ada sekarang tidak terperinci dan memberikan kebebasan bagi perusahaan untuk memilih menetapkan peraturan cuti haid di perusahaannya atau tidak. Hal ini penting dilakukan untuk menjamin adanya kepastian hukum dam perlindungan terhadap hak cuti haid bagi tenaga kerja perempuan di Indonesia.

Beberapa kasus mengenai cuti haid yang kami temukan, pihak tergugat (perusahaan) tidak banyak merespon terhadap tuntunan pekerja (penggugat) atas poin cuti haid. Padahal gugatan penggugat cukup jelas tetapi perusahaan mengalihkan keterangan di luar konteks gugatan yang sebenarnya. $\mathrm{Hal}$ ini menyebabkan kebingungan bagi pekerja, dikarenakan hasil dari keputusan pengadilan tidak terfokus pada cuti haid, melainkan pada hal-hal lain seperti pengupahan dan kedisiplinan kerja. Alangkah baiknya bila Pasal 81 UU Ketenagakerjaan memiliki peraturan pendukung lainnya yang bisa digunakan oleh penggugat dalam hal menuntutkan haknya di pengadilan sehingga kemungkinankemungkinan perusahaan untuk lari dari konteks gugatan dapat di minimalisir.

\section{DAFTAR PUSTAKA}

Asikin, Z. (2010). Dasar-Dasar Hukum Perburuhan. Jakarta: PT. Raja Grafindo Persada.

Asyhadie, Z. (2007). Hukum Kerja (Hukum Ketenagakerjaan bidang Hubungan Kerja. Jakarta: PT. Raja Grafindo Persada. 
Charda, U. (2017). Model Penyelesaian Perselisihan Hubungan Industrial Dalam Hukum Ketenagakerjaan Setelah Lahirnya Undang-Undang Nomor 2 Tahun 2004. Fakultas Hukum Universitas Subang, Jurnal Wawasan Yuridika, 1(1), 8.

Clinton, B., Lestari, R., \& Fitriani, R. (2016). Perlindungan Hukum Terhadap Hak Tenaga Kerja Wanita Di PT. Beka Engineering Pangkalan Kerinci (Doctoral dissertation, Riau University).

Dwiyanda, F. (2020). Pemutusan Hubungan Kerja Terhadap Pekerja/Buruh Perempuan Harian Lepas Oleh Perusahaan Karena Alasan Cuti Haid. Fakultas Hukum Universitas Airlangga, Media luris, 3(2), 134.

Djakaria, M. (2018). Perlindungan Hukum Bagi Pekerja Wanita Untuk Memperoleh Hak-Hak Pekerja Dikaitkan Dengan Kesehatan Reproduksi. Jurnal Bina Mulia Hukum, 3(1), 15-28.

Fakih, M. (2016). Analisis Gender dan Transformasi Sosial. Yogyakarta: Insist Press.

Flambonita, S. (2017). Perlindungan Hukum Terhadap Hak Pekerja Perempuan di Bidang Ketenagakerjaan. Simbur Cahaya, 24(1 Jan 2017), 43974424.

Hakim, A. (2003). Pengantar Hukum Ketenagakerjaan Indonesia. Jakarta: Aditya Bakti

Husni, L. (2004). Penyelesaian Hubungan Industrial Melalui

$\begin{array}{lll}\text { Pengadilan dan Di Luar } \\ \text { Pengadilan, Depok: } & \text { Raja } \\ \text { Grafindo Persada. }\end{array}$

Husni, L. (2014). Pengantar Hukum Ketenagakerjaan. Jakarta: Rajawali Pers.

Istakhori, K. (2017). Cuti Haid dan Lingkaran Eksploitasi Terhadap Buruh Perempuan di Tempat Kerja Studi Kasus Pelaksanaan Cuti Haid Pada Perusahaan Sektor Garmen dan Tekstil, Kertas, Penambang Batu Bara, Makanan dan Jasa di Propinsi DKI Jakarta, Jawa Barat, Jawa Timur, Sumatera Selatan, dan Riau. Sekolah Tinggi Hukum Indonesia, Jurnal Jentera, 1(2), 164.
Kartohadiprodjo,
Pengimpasan
S. (2003). (Kompensasi) dan Asas Kebebasan Berkontrak dalam Perjanjian Kredit Bank. Bandung: Utomo.

Khoe, F. N. (2013). Hak Pekerja yang Sudah Bekerja Namun Belum Menandatangani Perjanjian Kerja Atas Upah Ditinjau Berdasarkan Undang-Undang No. 13 Tahun 2003 Tentang Ketenagakerjaan. Jurnal Yustika, 2(1), 1-10.

Mahkamah Agung. (2013). Putusan $\mathrm{PHI}$ Mahkamah Agung Nomor 409 K/Pdt.Sus-PHI/2013. https://putusan3.mahkamahagun g.go.id/direktori/putusan/

Mambu, J. G. (2010). Aspek Perlindungan Hukum terhadap Pekerja Wanita (Menurut Undang-undang Nomor. 13 
Tahun 2003). De Jure: Jurnal Hukum dan Syar'iah, 2(2).

Mufidah, (2010). Bingkai Sosial Gender : Islam, Strukturasi, dan Konstruksi Sosial, Malang: UINMaliki Press.

Nurendah, R. (2014). Pelaksanaan Perlindungan Hukum Buruh Perempuan Atas Cuti Haid (Studi di Pabrik Rokok PT. Maica Nusantara Kabupaten Tuban). Jurnal Arena Hukum, 1(1), 1-10

Ramly, L. (2008), Hukum Ketenagakerjaan, Surabaya: Airlangga University Press.

Rusli, H. (2011). Hukum Ketenagakerjaan. Bogor: Ghalia Indonesia.

Soeroso. (2006). Penghantar Illmu Hukum. Jakarta: Sinar Grafika.

Sudharma, K. J. A., \& Widiati, D. P. Penyelesaian Sengketa Antara Tenaga Kerja Kontrak Dengan Perusahaan: Studi Kasus Sheraton Bali Kuta Resort. Kertha Semaya: Journal IImu Hukum, 8(10), 1528-1539.

Sugita, N. S., Markeling, I. K., \& Sudarsana, I. K. S. (2014). Pelaksanaan Perlindungan Hukum Bagi Pekerja Wanita Yang Bekerja Pada Malam Hari di Hard Rock Cafe Kabupaten Badung. Kertha Semaya: Journal IImu Hukum.
Tobing, C. N. (2018). Mengagas Pengadilan Hubungan Industrial dalam Bingkai lus Constituendum Sebagai Upaya Perwujudan Kepastian Hukum dan Keadilan. Fakultas Hukum Universitas Pelita Harapan, Law Review, 7(2), 297.

Widianti, A. (2005). Hukum Berkeadilan Gender. Jakarta: Kompas.

Wijayanti, A. (2010). Hukum Ketenagakerjaan Pasca Reformasi. Jakarta: Sinar Grafika.

Van Wijk.H.D/Willem Konijnenbelt, 1988, Hoofdstrukken van administratief Recht, Uitgeverij Lemma B.V. 